\title{
Influence of grazing lease terms on economic optimal stocking rates
}

\author{
GARY J. MAY, RODNEY D. JONES, MICHAEL R. LANGEMEIER, AND KEVIN C. DHUYVETTER
}

\begin{abstract}
Authors are Extension Program Specialist, Department of Economics, Iowa State University, Ames, Iowa 50011; Associate Professor, Professor, and Professor, Department of Agricultural Economics, Kansas State University, Manhattan, Kans. 66506.
\end{abstract}

\begin{abstract}
The terms of grazing lease contracts potentially influence a tenant's incentive to preserve the vegetation resource. Annual stocking rate decisions dictate the degree of overgrazing, which can be cumulative over long periods of time. The objective of this study was to identify the impact the tenant's lease length and lease type has on profit maximizing stocking rates. A multi-period nonlinear programming model was developed to identify economically optimal stocking rates each year over a 24-year period. The model was solved under 1-, 4-, 8-, and 12-year leases on a "per ha" and "per head" basis. The relative importance of each lease alternative and other input values in explaining the tenant's optimal stocking rate was ranked based on standardized ordinary least squares coefficient estimates. Lease length and lease type had a minor impact on optimal stocking rates relative to non-lease factors such as livestock prices and production costs. Holding lease length constant, per ha leases generated a $2 \%$ higher average stocking rate than per head leases. Optimal stocking rates were inversely related to the length of the lease. Twelveyear leases generated 18 and $13 \%$ lower optimal stocking rates than the 1-year per ha and per head leases, respectively. The optimal stocking rate difference between an 8-year and a 12-year lease was negligible, suggesting the 8-year lease would provide a similar incentive to protect vegetation as a lease with a longer planning horizon.
\end{abstract}

Key Words: Lease Type, Lease Length, Standardized Beta Coefficient

Alternative lease arrangements influence soil and vegetation protection incentives faced by agricultural producers. Overgrazing is a common cause of declining ecological condition on rangeland and pasture (Ellison 1960). Stocking rate, defined as the number of animals on a given land area for a fixed period of time, is the primary decision variable management can use to control overgrazing. Profit-maximizing stocking rates may vary depending on the livestock operator's property rights associated with the land. The type and duration of grazing leases impact tenant stocking rate incentives by influencing the planning horizon, and/or the cost structure of the grazing enterprise.

\section{Length of the Lease}

The length of the planning horizon often is cited as an important factor in the livestock producer's incentive to stock appropri-

Manuscript accepted 30 Oct. 01 .

\section{Resumen}

Los términos de los contratos de arrendamiento de pastoreo influencian potencialmente el incentivo del arrendatario por conservar el recurso vegetación. Decisiones del rango del inventario ganadero anual dictan el grado de sobre pastoreo, el cual puede ser acumulativo sobre largos periodos de tiempo. El objetivo de este estudio fue identificar el impacto que la duración del arrendamiento así como el tipo de arrendamiento tienen en la maximización de ganancias de los rangos de inventario ganadero. Un modelo de programación no linear de multiperiodo fue desarrollado para identificar rangos de inventario económicamente óptimos cada año en un periodo de 24 años. El modelo fue resuelto bajo 1-, 4-, 8-, basándose en "por hectárea" y "por cabeza" durante 12 años de arrendamiento. La importancia relativa de cada alternativa de arrendamiento y otros valores al explicar el rango optimo de inventario del arrendatario fue clasificada basada en estimaciones estandarizadas de los coeficientes de los cuadrados mínimos ordinarios. Duración del arrendamiento y tipo de arrendamiento tuvieron un impacto menor en los rangos óptimos de inventario relativos a factores no relacionados con el arrendamiento como precios del ganado y costos de producción. Manteniendo la duración del arrendamiento constante, arrendamiento por hectárea generó un $2 \%$ mas en promedio que el arrendamiento por cabeza. Rangos óptimos de inventario fueron relacionados inversamente a la duración del arrendamiento. Doce años de arrendamiento generaron 18 y $13 \%$ rangos óptimos de inventario menores que el arrendamiento de 1 año por hectárea por cabeza, respectivamente. La diferencia del rango optimo de inventario entre arrendamientos de 8 y 12 años fue insignificante, sugiriendo que el arrendamiento por 8 años proveería un incentivo similar para proteger la vegetación que el de un arrendamiento con un horizonte de planeación más amplio.

ately (Torell et al. 1991, Workman 1986). The length of a grazing lease may represent the planning horizon for land operated by a tenant with uncertain lease renewal prospects. Relatively short leases, therefore, may encourage tenants to overstock and exploit the forage resource for short-term profitability at the expense of long-term pasture productivity. A short-term planning horizon, however, does not guarantee that a tenant will have an economic incentive to overgraze. Because individual weight gain decreases as stocking rate increases, excessive stocking can reduce profitability, even with a single year planning period. For example, Launchbaugh (1957) conducted grazing trials near Hays, Kansas, and found that light stocking rates were usually more profitable than heavy stocking rates. Shoop and McIlvain (1971) suggest 
producers who overgraze usually are not behaving in their economic self-interest. Workman (1986) suggests overgrazing is usually a result of ignorance and overoptimistic forage production estimates, and occurs in spite of the profit motive, not because of it.

Several studies estimating economic optimal stocking rates suggest livestock operators periodically have an incentive to deplete or "mine" the forage resource. Hart et al. (1988) estimated the profitmaximizing stocking rate near Cheyenne, Wyo., assuming 1986-1987 price/cost conditions, to be 60 to $80 \%$ above the Soil Conservation Service (now NRCS) recommended level to maintain range condition. Manley et al. (1997) reported that stocking rates 30 to $75 \%$ higher than the NRCS recommended level were profitable during favorable cattle price periods. McCollum et al. (1999) found the most profitable stocking rate under continuous grazing in tall-grass prairie exceeded NRCS recommendations.

These studies used single-period models and did not consider the impact of the current stocking rate decision on future forage production. Evaluating stocking rate incentives under alternative forms of land tenure requires a model that considers the decision maker's relevant multi-year planning horizon. Dynamic optimization models consider the impact of future pasture productivity and profitability by maximizing the sum of the discounted income stream over the relevant time horizon. Pope and McBryde (1984) used a dynamic optimization model to compare the profitability of systematic overstocking coupled with periodic re-vegetation treatments to maintaining a sustainable stocking rate. Optimal stocking rates approached the biological sustainable level as the planning horizon increased to perpetuity. The grazing strategy that maximized the sum of the discounted cash flow streams was to slightly overgraze and deplete the forage over a 10 -year planning horizon.

Torell et al. (1991) compared optimal stocking and forage utilization rates for a single period model to an expanded model with a multi-period planning horizon based on Colorado production data (Sims et al. 1976). Profit-maximizing stocking rates were slightly lower in the dynamic (long-term horizon) model relative to the myopic (single-period) model. With variable beef price situations, economically optimal stocking rates were variable and rangeland productivity was not greatly reduced with either a single period or a long term planning horizon. The authors concluded that inter-temporal impacts on forage production were a relatively minor consideration in the current stocking rate decision. Current period animal performance at alternative stocking rates was the most important consideration in the stocking rate decision.

\section{Cost Structure}

Economically optimal stocking rates are influenced by the cost and revenue structure of the grazing enterprise (Hart 1991, Workman 1986). The grazing lease type (per head or per ha lease payments) influences the cost structure of the grazing enterprise, and, consequently, profit-maximizing stocking rates. Cost structure refers to the proportion of total costs categorized as fixed or variable. Fixed costs do not change with the level of production. Examples of typical fixed costs include interest, insurance, and depreciation. Variable costs change with the level of production. Typical variable costs in a livestock operation include feed, veterinary care, animal care, and other costs that change with the number of head.

When lease contracts specify compensation on ha basis, lease payments are fixed costs with respect to stocking rate. In this situation, total lease costs are unrelated to the stocking rate. Tenants operating under this type of lease can reduce per-head costs by increasing stocking rates. The tially a public issue as excessive grazing can impact aesthetic values, noxious weed encroachment, and downstream water quality. Furthermore, tenant operators manage a substantial portion of Kansas grazing lands. These externalities create a public interest in whether certain lease contracts systematically encourage overgrazing. Promoting lease terms that reduce tenant incentive to overgraze may be an effective method of addressing these issues. The objective of this study was to explore the relationship between alternative lease types common to grazing land and economically optimal stocking rates. This relationship is then compared to the impact of non-lease influences such as livestock prices and production costs.

\section{Methods}

Nonlinear programming models were used to estimate the optimal stocking rate on Kansas Flint Hills pasture each year over a 24-year period under 2 alternative lease types (per ha and per head) and 4 alternative lease lengths $(1,4,8$, and 12 years). The model combined livestock prices, lease rates, and production costs observed each year from 1975-1998. The objective function of each model was specified as follows:

$$
\begin{aligned}
\operatorname{Max} \pi_{\mathrm{k}} & =\sum_{\mathrm{t}=1}^{\mathrm{k}}\left[\mathrm{HD}_{\mathrm{t}} *\left(\mathrm{OSP}_{\mathrm{t}} * \mathrm{OSW}_{\mathrm{t}}-\mathrm{MSP}_{\mathrm{t}} * \mathrm{MSW}_{\mathrm{t}}-\mathrm{VCH}_{\mathrm{t}}-\mathrm{LRH}_{\mathrm{t}}\right) /(1+\mathrm{r})^{\mathrm{t}}\right] \\
\operatorname{Max} \pi_{\mathrm{k}} & =\sum_{\mathrm{t}=1}^{\mathrm{k}}\left[\left\{\mathrm{HD}_{\mathrm{t}} *\left(\mathrm{OSP}_{\mathrm{t}} * \mathrm{OSW}_{\mathrm{t}}-\mathrm{MSP}_{\mathrm{t}} * \mathrm{MSW}_{\mathrm{t}}-\mathrm{VCH}_{\mathrm{t}}\right)-\mathrm{LRA}_{\mathrm{t}} * 260\right\} /(1+\mathrm{r})^{\mathrm{t}}\right]
\end{aligned}
$$

level of fixed costs does not affect the stocking rate decision in the short run but all costs must be covered in the long run (Workman 1986).

Lease payments are a variable cost (per ha) when the lease calls for compensation on a per head basis. In this situation, total lease costs are directly related to stocking rates. The profit-maximizing stocking rate occurs where the additional (marginal) revenue generated by each additional animal equals the additional (marginal) cost. Given diminishing marginal productivity as animals are added to the pasture, profit maximizing stocking rates are reduced as the per head lease rate increases. Conversely, stocking rate in the per ha lease type does not affect the lease component of marginal costs. This implies per ha leases may encourage tenants to stock heavily relative to per head leases.

Management of private pasture is poten-
Equations 1 and 2 represent the objective functions for the per head (hereafter denoted head lease) and per ha lease (hereafter denoted ha lease) models, respectively. The decision variable in each model is the number of head $\left(\mathrm{HD}_{\mathrm{t}}\right)$ stocked on a full section (260 ha) pasture each year. The symbol $\pi_{k}$ represents cumulative pasture profitability over the length of the lease. Cumulative pasture profitability is evaluated on a per section basis regardless of the leased type or lease length evaluated. The symbols $\mathrm{MSW}_{\mathrm{t}}$ and $\mathrm{OSW}_{\mathrm{t}}$ represent to May steer weight and October Steer Weight, respectively. For this study, MSW was assigned a constant value of $270 \mathrm{~kg}$ every year and OSW is determined by Equation 3. The remaining symbols, $\mathrm{MSP}_{\mathrm{t}}$ and $\mathrm{OSP}_{\mathrm{t}}$, represent May Steer Price and October Steer Price, respectively.

$$
\mathrm{OSW}_{\mathrm{t}}=\mathrm{MSW}_{\mathrm{t}}+\mathrm{DOP}_{\mathrm{t}} * \mathrm{ADG}_{\mathrm{t}}
$$


The model based future stocking rate decisions on expected rather than actual livestock prices. Table 1 shows the

Table 1. Method of modeling price expectations in a 4-year lease.

\begin{tabular}{lllll}
\hline \hline & \multicolumn{3}{c}{ Solved for years } \\
\cline { 2 - 5 } Decision year & 1 & 2 & 3 & 4 \\
\hline 1 & A & B & B & B \\
2 & & A & B & B \\
3 & & & A & B \\
4 & & & & A \\
\hline
\end{tabular}

$\mathrm{A}=$ The stocking decision was based on the actual observed May steer price, and a basis adjusted futures price for the October steer price.

$\mathrm{B}=$ The stocking decision was based on 5-year moving average cash prices for both May steer price and October steer price.

method of modeling price expectations over multi-year leases using a 4-year lease as an example. In the first year of the lease, the model determined stocking rates for years 1 through 4 . In year 2 of the lease, the model was solved for years 2 through 4 based on new price information observed in year 2 and vegetative conditions inherited from the previous year. In the third year, the model was solved for years 3 and 4, while in the fourth year, the model was solved for year 4 . The model moved on to the next lease period and repeated this process based on new price expectations and vegetative conditions inherited from the previous lease period. This method allowed the model to allocate the effects of the current stocking rate decision over the relevant planning horizon based on expected long- and shortterm cattle prices.

Price expectations used in the model were formed using May and October Dodge City, Kansas, feeder cattle prices from 1975 through 1998. Price expectations for the October steer price in the 1year models, and year $t$ in the multi-year lease models, were basis adjusted October futures prices observed in May. Price expectations for both May and October steer prices for years $t+1$ through $k$ of the multi-year lease models were based on 5year moving average cash prices. All price and cost data were expressed in nominal dollars.

Calf prices typically decrease as the weight of the animal increases (Dhuyvetter and Schroeder 2000). This trend, referred

${ }^{1}$ Dhuyvtter and Schroeder (2000) found a non-linear price slide over a relatively extreme range of cattle weights. For the weight range relevant to this study, however, a linear price slide was a close approximation. to as the weight price slide, was approximated with a linear interpolation between prices of 315 and $360 \mathrm{~kg}$ steers observed each year (Dhuyvetter ${ }^{1}$ and Schroeder 2000, Mark et al. 2000). The model used the average price slide of $\$-0.04(100 \mathrm{~kg})^{-1}$ observed over the study period. For each kilogram increase in October steer weight, the October steer price decreases by $\$ 0.04$ $(100 \mathrm{~kg})^{-1}$.

Operating costs included in the model are normally incurred on a per head basis. Operating cost estimates were taken from Kansas summer stocker budgets compiled by Jones and Dhuyvetter (1999), and include interest on purchased livestock, veterinary care, labor, mineral, and miscellaneous costs. A continuous operating cost data series was not available for the fore, were assigned to each year by inflating Jones and Dhuyvetter (1999) estimates using the producer price index. Interest on purchased livestock was calculated from operating loan rates observed each year and reported by the Federal Reserve Bank of Kansas City (1975-1998).

Equations 3 through 7 express the relationships that limit the optimal stocking rate. In Equation 3, the coefficient $\mathrm{DOP}_{t}$ refers to the days on pasture in year $t$ and was assigned a constant value of 150 days. Equation 4 defines average daily gain (ADG) in year $t$.

$$
\mathrm{ADG}_{\mathrm{t}}=1.00-0.0029 * \mathrm{GP}_{\mathrm{t}} ;
$$

The linear function was taken from Torell et al. (1991) but coefficient values were recalibrated to match weight gains observed at various stocking rates in the Kansas Flint Hills tallgrass region (Smith and Owensby 1978, Launchbaugh and Owensby 1978). A linear relationship between stocking rate and ADG is supported by research over a wide range of relevant time period. Nominal costs, there-

geographic locations (Hart 1972,1993, Jones and Sandland 1974, Manley et al. 1997). Specifying average daily gain as a linear function of grazing pressure implies livestock gain ha ${ }^{-1}$ is a quadratic function of stocking rate. The models, therefore, have a non-linear objective function.

Figure 1 shows the per head and per ha stocking rate weight gain response functions derived from Equation 4. These functions assume forage production levels of $3,600 \mathrm{~kg} \mathrm{ha}^{-1}$. The inverse relationship between stocking rate and weight gain head $^{-1}$ limits the economic incentive to overgraze. Maximum weight gain per head at very low stocking rates was approximately $150 \mathrm{~kg}$ over the entire grazing season, representing an average daily gain of $1.0 \mathrm{~kg}$. Maximum weight gain per ha was approximately $30 \mathrm{~kg}$ at a stocking rate of 260 head for the grazing season. Reducing the forage production assumption shifts the curves downward but does not change the slope.

Equation 5 defines grazing pressure in year $t\left(G P_{t}\right)$ as stocker days per unit of available standing herbage (Hart et al. 1988). Available forage $\left(\mathrm{AF}_{t}\right)$, represented in Equation 6, is a function of pasture forage production capacity (FPC) and the herbage production index in year $\mathrm{t}\left(\mathrm{HPI}_{\mathrm{t}}\right)$. Pasture FPC was exogenously assigned the equivalent of $3,600 \mathrm{~kg} \mathrm{ha}$ (Launchbaugh and Owensby 1978).

$$
\begin{aligned}
\mathrm{GP}_{\mathrm{t}} & =\mathrm{HD}_{\mathrm{t}} * \mathrm{DOP}_{\mathrm{t}} / \mathrm{AF}_{\mathrm{t}} \\
\mathrm{AF}_{\mathrm{t}} & =\mathrm{FPC} * \mathrm{HPI}_{\mathrm{t}}
\end{aligned}
$$

The herbage production index in year $t$ $\left(\mathrm{HPI}_{\mathrm{t}}\right)$ expressed in Equation 7 provides the link between past grazing pressure and current forage production.

$$
\begin{aligned}
& \mathrm{HPI}_{\mathrm{t}}=0.4343+0.5824 \mathrm{HPI}_{\mathrm{t}-1}-0.00136 \\
& \mathrm{GP}_{\mathrm{t}-1}
\end{aligned}
$$

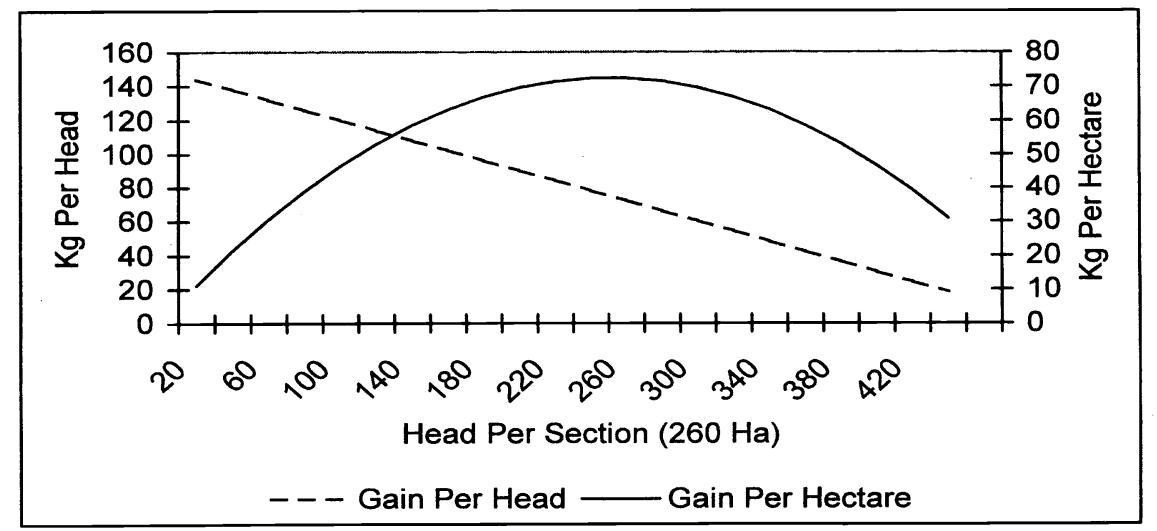

Fig. 1. Functional relationship between stocking rate and weight gain on a per head and per ha basis. 
Ranging between zero and one, $\mathrm{HPI}_{t}$ values represent the proportion of forage production capacity available for grazing in year $t$. The functional form and coefficient values were derived from Torell et al. (1991). Specifying $\mathrm{HPI}_{t}$ as a function of the previous year grazing pressure and HPI suggest $\mathrm{HPI}_{t}$ is an implicit function of all past grazing pressure levels.

The model determined the optimal stocking each year considering impacts on future forage production through the remainder of the lease period. Future income was discounted at the nominal rate of $11.5 \%$ per year. This rate represents the average operating loan rate over the 24year study period reported by the Federal Reserve Bank of Kansas City (19751998).

The lease rates assigned to each period were regional averages taken from the Bluestem Pasture Report (Kansas Agricultural Statistics Service 1975-1998). For example, the lease rate assigned to the first period of the 4-year model was the average lease rate observed from 1975-1978. The lease rate for the second 4 years was the average rate observed between 1979-1982. This pattern applied to all lease models.

Head leases were modeled in this study as a mixed cost structure, rather than a strict variable lease cost. Multi-year lease contracts, by definition, guarantee a minimum annual payment for the duration of the lease. Consequently, even per head lease payments would realistically have a fixed cost component as a tenant may be under a contractual obligation to make lease payments based on some pre-specified stocking rate. A landlord would unlikely accept a tenant wishing to pay for very few head. This suggests a tenant would face some minimum lease payment with a value independent of the number of head actually stocked.

The next issue in setting minimum lease payments in the head model was identifying what stocking rate should the minimum lease payment be based. In the Kansas Flint Hills, landowners offering per head leases guarantee a minimum land area per head (Kansas Agricultural Statistics 1975-1998). The acreage guarantee varies from year to year based on vegetative and market conditions, and this value is reported annually in the Bluestem Pasture Report (Kansas Agricultural Statistics 1975-1998). The reciprocal of the acreage guarantee observed each year was considered an approximation of the minimum stocking rate dictated by the grazing lease market. In the model, the tenant was obligated to pay for at least the number of head the acreage guarantee would suggest, but was to free stock the pasture at any level. Lease costs increased linearly by the head lease rate for stocking rates greater than the level established by the acreage guarantee.

\section{Sensitivity Analysis}

The relative importance of lease type, lease length, livestock prices, and production costs in the stocking rate decision was ranked based on standardized ordinary least squares regression coefficients estimated using the models represented in Equations 8 and 9.

$$
\begin{aligned}
& \mathrm{HD}_{\mathrm{t}}^{*}=f\left(\mathrm{LENGTH}_{\mathrm{t}}, \mathrm{TYPE}_{\mathrm{t}}, \mathrm{VC}_{\mathrm{t}},\right. \\
& \text { MSP } \left._{\mathrm{t}}, \mathrm{OSP}_{\mathrm{t}}\right) \\
& \mathrm{HPI}_{\mathrm{t}}^{*}=f\left(\mathrm{LENGTH}_{\mathrm{t}-1}, \mathrm{TYPE}_{\mathrm{t}-1},\right. \\
& \left.\mathrm{MSP}_{\mathrm{t}-1}, \mathrm{OSP}_{\mathrm{t}-1}\right)
\end{aligned}
$$

The dependent variable $\mathrm{HD}_{\mathrm{t}}{ }^{*}$ denotes the optimal stocking rate values generated each year by the models represented by Equations 1 and 2. The dependent variable $\mathrm{HPI}_{\mathrm{t}}{ }^{*}$ denotes the herbage production index value generated by Equation 7 at each HD* ${ }^{*}$. The independent variables in Equations 8 and 9 were input values used by models 1 and 2 to generate each HD* observation. The variable LENGTH denotes the lease length used to generate each observation of $\mathrm{HD}_{\mathrm{t}}{ }^{*}$, assuming a discrete value of $1,4,8$, or 12 years. Lease type (TYPE) was a binary variable assigned a value of 0 if the lease was specified on a per head basis, and a value of 1 if the lease was specified on a per ha basis. The variable $\mathrm{VC}_{t}$ denoted variable operating costs observed each year, while $\mathrm{MSP}_{t}$ and $\mathrm{OSP}_{\mathrm{t}}$ represent May steer price and October steer price, respectively. Since $\mathrm{HPI}_{t}$ is a function of previous year grazing pressure and herbage production index, the independent variables in Equation 9 were all lagged 1 year. The variable $\mathrm{VC}_{\mathrm{t}}$ was omitted from Equation 9 because of confounding trends in the data. Models 8 and 9 each had 156 observations, 24 years model $^{-1}$ times 8 models ( 2 lease types times 4 lease length alternatives).

Standardizing estimated coefficients entails scaling ordinary least squares coefficient estimates by the ratio of the standard deviation of the relevant independent variable to the standard deviation of the dependent variable (Pindyck and Rubinfeld 1998). This calculation converts ordinary least squares estimates to unitfree coefficients whose absolute magnitudes are directly comparable, revealing the relative impact of the independent variables on the dependent variable.
Simply put, this technique reveals how many standard deviations the dependent variable is expected to change in response to a standard deviation change in each respective independent variable (Mark et al. 2000, Featherstone et al. 1997).

Parametric analysis was used to examine the sensitivity of the model to other input variables that could potentially affect the results. Inter-temporal vegetative condition responses to grazing pressure would potentially influence the relationship between planning horizon and the current stocking rate decision. This relationship was incorporated into the model through Equation 7. The coefficient values in Equation 7 were estimated from data collected in eastern Colorado (Sims et al. 1976). These values may depend on regional growing conditions and, therefore, may not accurately represent eastern Kansas. Parametric analysis was used to identify the sensitivity of the results to changes in the coefficients. Each model was solved after changing coefficient and constant values, one term at a time, to 80 and $120 \%$ of the original estimates.

To compare leases with alternative time horizons, future income flows should be discounted to present value. Discounting places a greater value on income received in the near future relative to the distant future, increasing the incentive to mine the forage. The rate at which future income is discounted may impact the stocking rate decision. The discount rate, however, may not have a significant impact on optimal stocking rates if price/cost conditions frequently do not favor exceeding the steady state grazing pressure. Sensitivity of average optimal stocking rates to the discount rate was evaluated by comparing the results at alternative discount rates.

\section{Results}

\section{Optimal Stocking Rates}

Table 2 shows the optimal number of head stocked on the pasture each year under head and ha lease types. The average number of steers stocked on the 260 ha pasture in the 1-year ha lease scenario was 144 head, while the solution for the 4-, 8 -, and 12-year leases were 130, 124, and 122 , respectively. The head lease type reveals a similar trend. The average number of steers stocked was 136, 131, 123, and 120 head in the 1-, 4-, 8-, and 12-year leases, respectively.

As the length of the lease increased, average optimal stocking rate decreased. The largest decrease in the ha lease type 
Table 2. Optimal number of head stocked in a full-section pasture each year under alternative lease agreements.

\begin{tabular}{|c|c|c|c|c|c|c|c|c|}
\hline & \multicolumn{4}{|c|}{ Per Hectare Leases } & \multicolumn{4}{|c|}{ Per Head Leases } \\
\hline & 1-Year & 4-Year & 8-Year & 12-Year & 1-Year & 4-Year & 8-Year & 12-Year \\
\hline Year & \multicolumn{8}{|c|}{$\ldots \ldots \ldots$ Head Per Section (260 ha) $\ldots \ldots \ldots$} \\
\hline 1975 & 218 & 135 & 122 & 122 & 156 & 235 & 203 & 196 \\
\hline 1976 & 238 & 223 & 215 & 215 & 152 & 62 & 36 & 35 \\
\hline 1977 & 221 & 221 & 204 & 203 & 152 & 152 & 152 & 152 \\
\hline 1978 & 137 & 152 & 121 & 120 & 145 & 231 & 145 & 145 \\
\hline 1979 & 167 & 156 & 173 & 171 & 157 & 108 & 122 & 117 \\
\hline 1980 & 128 & 110 & 118 & 110 & 139 & 139 & 139 & 139 \\
\hline 1981 & 160 & 161 & 160 & 142 & 142 & 142 & 142 & 134 \\
\hline 1982 & 103 & 116 & 119 & 66 & 125 & 145 & 145 & 105 \\
\hline 1983 & 113 & 68 & 63 & 87 & 125 & 49 & 60 & 70 \\
\hline 1984 & 147 & 123 & 113 & 135 & 145 & 145 & 145 & 145 \\
\hline 1985 & 155 & 159 & 144 & 166 & 142 & 107 & 89 & 112 \\
\hline 1986 & 110 & 125 & 62 & 128 & 119 & 172 & 145 & 181 \\
\hline 1987 & 106 & 64 & 80 & 59 & 110 & 145 & 145 & 145 \\
\hline 1988 & 108 & 80 & 88 & 68 & 110 & 128 & 139 & 120 \\
\hline 1989 & 134 & 123 & 129 & 99 & 135 & 149 & 149 & 139 \\
\hline 1990 & 109 & 123 & 125 & 70 & 110 & 140 & 144 & 102 \\
\hline 1991 & 121 & 89 & 85 & 98 & 122 & 56 & 54 & 56 \\
\hline 1992 & 134 & 104 & 92 & 99 & 134 & 152 & 152 & 152 \\
\hline 1993 & 112 & 103 & 84 & 87 & 113 & 112 & 81 & 81 \\
\hline 1994 & 144 & 159 & 127 & 129 & 144 & 98 & 74 & 71 \\
\hline 1995 & 162 & 131 & 145 & 146 & 149 & 149 & 149 & 149 \\
\hline 1996 & 141 & 102 & 108 & 109 & 144 & 156 & 156 & 156 \\
\hline 1997 & 139 & 142 & 145 & 145 & 143 & 117 & 126 & 125 \\
\hline 1998 & 142 & 161 & 162 & 163 & 141 & 55 & 57 & 57 \\
\hline Average & 144 & 130 & 124 & 122 & 136 & 131 & 123 & 120 \\
\hline
\end{tabular}

occurred when the lease increased from 1 to 4 years, while the largest increase in the head lease type occurred between the 4and 8-year leases. In both head and ha leases, the optimal stocking rate difference between 8- and 12-year leases was minimal. Average stocking rate in the 1-year ha and head lease agreements was 22 and 16 head greater than the corresponding 12year lease agreements. This represents an 18 and $13 \%$ difference in optimal stocking rates between the extreme lease length scenarios included in the study. Furthermore, there was a large degree of year-to-year variability in optimal stocking rates with all lease arrangements, corresponding largely to the variation in annual beef prices used in the analysis.

The ha lease type generated an average profit-maximizing stocking rate similar to the head lease type. Removing the landlord imposed minimum lease payment, however, substantially reduced the optimal stocking rate in the head lease type. Solving the 1-year model using a strictly variable head lease type reduced the average optimal stocking rate to 91 head section $^{-1}$. This represents a 33 and $37 \%$ reduction in average optimal stocking rates relative to the original head and ha models. Furthermore, solving the 1-year model based on a strictly variable per head lease generated a lower optimal stocking rate than the long-term leases with a fixed cost component.
0.75 , and 0.76 in the 1-, 4-, 8-, and 12-year ha leases, and $0.71,0.71,0.75$, and 0.76 in the 1-, 4-, 8-, and 12-year head leases, respectively.

All grazing leases examined in this study periodically reached optimal grazing intensities that reduced herbage production index (HPI) levels. The 1-year ha lease achieved the lowest herbage production index value for all models considered in the study, 0.54 observed in 1982. This index value suggests that economically optimal stocking rates reduced forage production to $54 \%$ of its capacity. Lease type impact on HPI values appears to decline as the lease length increases. Mean HPI values were five percentage points higher in the head relative to the ha lease type, but equivalent in the 8-and 12-year leases.

\section{Factors Influencing Optimal Stocking Rates}

Figure 4 graphically illustrates, in decreasing order of importance, the relative impact of cattle prices, production costs, lease type, and lease length in the profit-maximizing stocking rate, based on standardized coefficient values from the regression. Cattle prices were the most important factors influencing optimal stocking rates. For each standard deviation in livestock purchase and selling prices above the mean, optimal stocking rates decrease by 1.327 and increase by 1.169 standard deviations, respectively, from its mean. As expected, variable operating costs were inversely related to stocking rates. All variables included in Figure 4, except lease type, were statistically significant $(p=0.05)$. The $R^{2}$ value of 0.289 was relatively low. This value, however, was robust over a variety of functional forms, suggesting specification error is not likely.

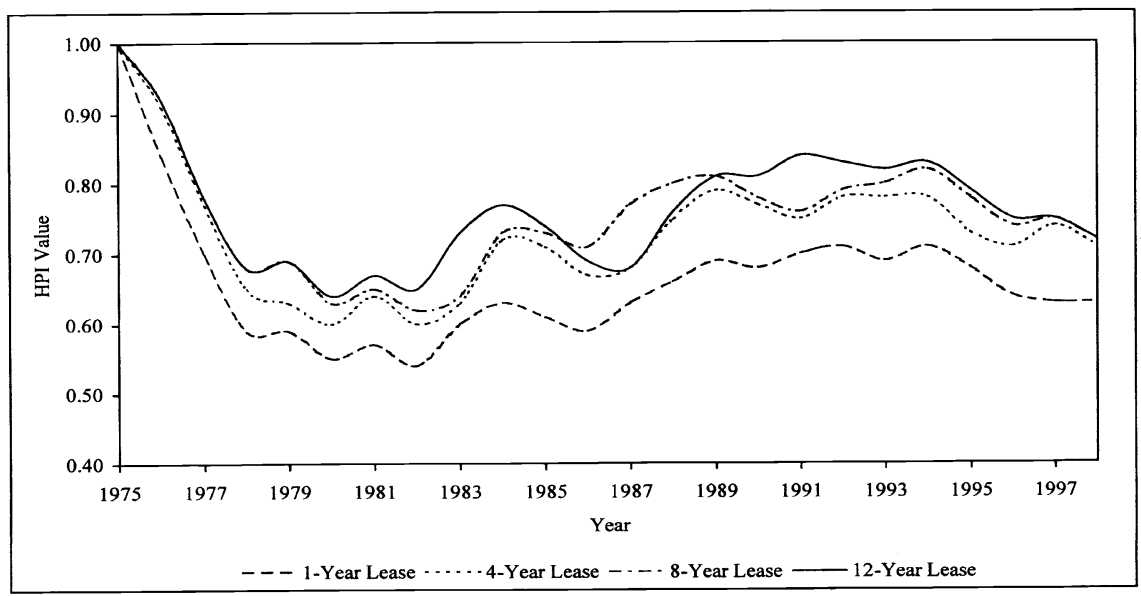

Fig. 2. Optimal HPI time path under alternative ha lease agreements. 


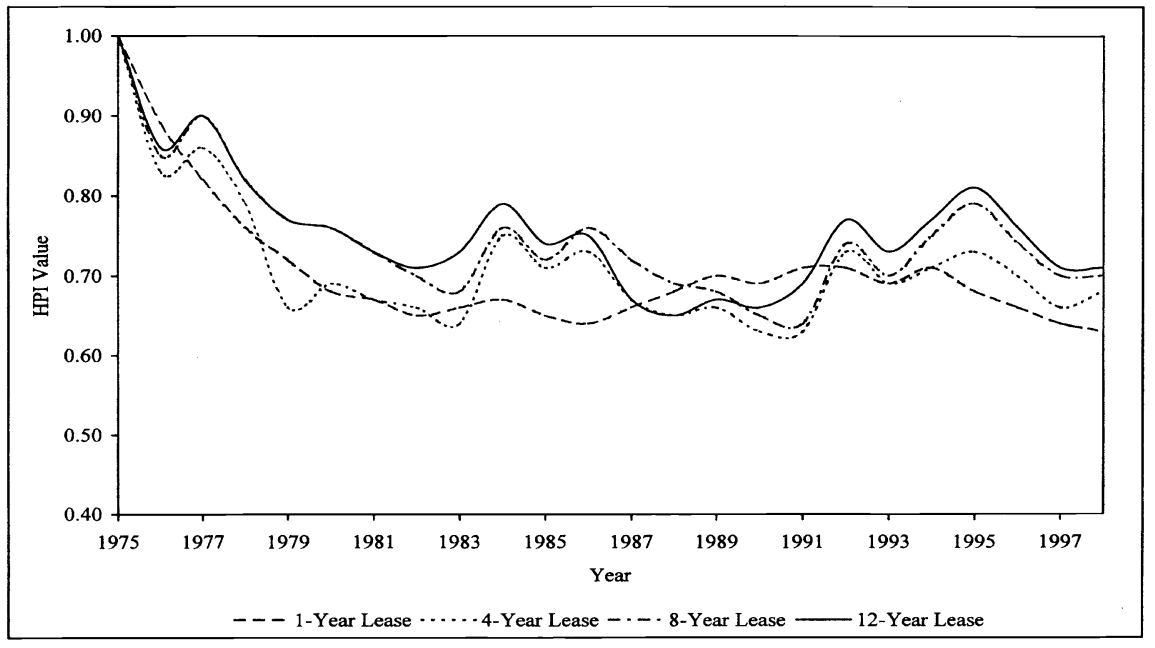

Fig. 3. Optimal HPI time path under alternative head lease types.

Grazing lease terms modeled in the study, lease type and lease length, were the lowest-ranked factors explaining the variability in the tenant optimal stocking rate. Regression results suggest that holding other variables in Equation 8 constant, the ha lease type increased optimal stocking rates by an average of 2 head section ${ }^{-1}$ relative to the head lease. In addition, the length of the lease had a relatively minor impact on optimal stocking rates. These results suggest expected short-term livestock price/cost margins and the stocking rate weight gain trade-off carry a larger influence on current optimal stocking rates than expectations regarding future forage production.

\section{Factors Influencing HPI Values}

Figure 5 shows the impact of cattle prices, and lease terms on estimated herbage production index (HPI) values. Since HPI values are inversely related to stocking rate (Equation 5), factors influencing stocking rates could also be expected to influence HPI values. Figure 5 supports this expectation. The ranking was similar to the stocking rate value factors illustrated in Figure 3 . The signing of the coefficients, however, was opposite. The October steer price had the greatest impact on herbage HPI with a standardized coefficient value of -1.731 , followed by May steer price with a value of 1.498 . Lease length and lease type carried the lowest impact on optimal stocking rates, with standardized coefficient values of 0.409 and -0.029 , respectively. Consistent with Figure 4, all variables except lease type were statistically significant $(\mathrm{p}=0.05)$.

\section{Parametric Analysis Results}

The discount rate apparently does not have a large influence on the optimal stocking rate. Reducing the discount rate from 11.5 to $6 \%$ reduced average optimal

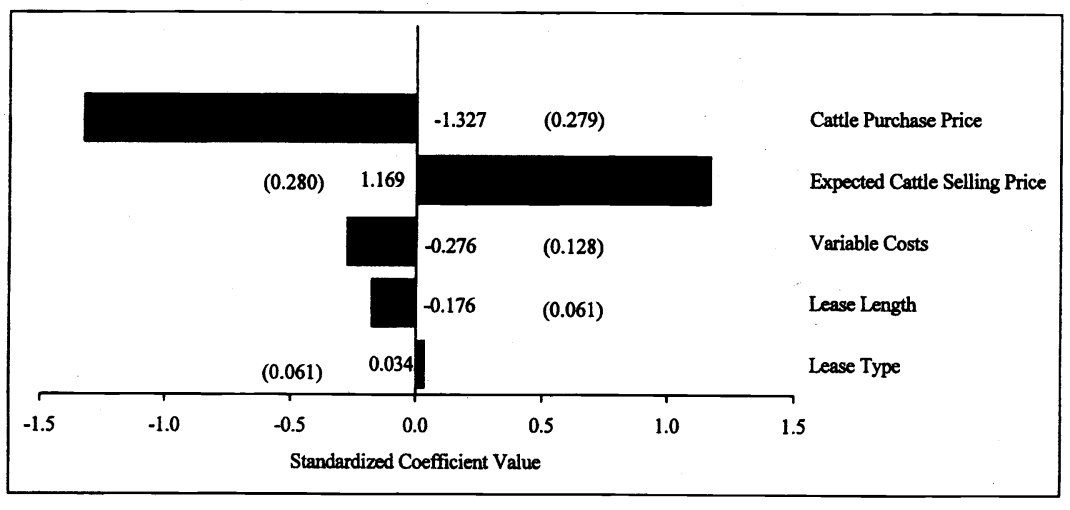

Fig. 4. Relative impact of each input variable on profit-maximizing stocking rates $\left(R^{2}=\right.$ 0.289). Standard errors are in parentheses. stocking rate by 1,2 , and 2 head section $^{-1}$ in the 4-, 8-, and 12-year ha lease types, respectively. The discount rate reduction had a similar impact on the head lease type, reducing optimal stocking rate by 0 , 1 , and 1 head section ${ }^{-1}$ in the 4-, 8-, and 12-year models, respectively.

Adjusting the coefficient values in Equation 7 affects optimal stocking rates and herbage production index values, but not the relative importance of lease terms and livestock prices. In all cases, rankings were consistent with the base results shown in Figures 2 and 3. Of the 3 terms in Equation 7, previous year herbage production index had the greatest impact on optimal stocking rates.

\section{Discussion and Conclusions}

Understanding the interaction between economic incentives and long-term physical impacts on grazing land is an important component for addressing management-induced pasture deterioration. Expected livestock price/cost margins emerged as the most important factors in the stocking rate decision. This result may diminish the opportunity for landlords, public agencies, or other stakeholders to indirectly address vegetative condition by promoting grazing leases of specific length or type. A landlord wishing to maintain a minimum vegetative condition may need to directly specify appropriate stocking rates in the lease.

\section{Effect of Lease Length}

Although livestock prices and operating costs clearly play a dominant role in the stocking rate decision, short-term pasture leases may promote heavier stocking rates than long-term leases. As the length of the lease increased, the optimal stocking pattern appears to approach that of an owneroperator with a perpetual planning horizon ${ }^{2}$. The 24-year lease model generated results similar to the 12-year lease model. Furthermore, optimal stocking rates in the 12-year lease were only slightly lower than the 8-year lease. These results suggest that, holding lease type constant, an 8-year lease would provide a stocking rate incentive similar to a land tenure alternative providing a perpetual planning horizon.

\footnotetext{
${ }^{2}$ The models were solved assuming an owner-operator land tenure arrangement (essentially an infinite planning horizon). The average profit maximizing stocking rate over the 24 year time period was 121 head section ${ }^{-1}$.
} 


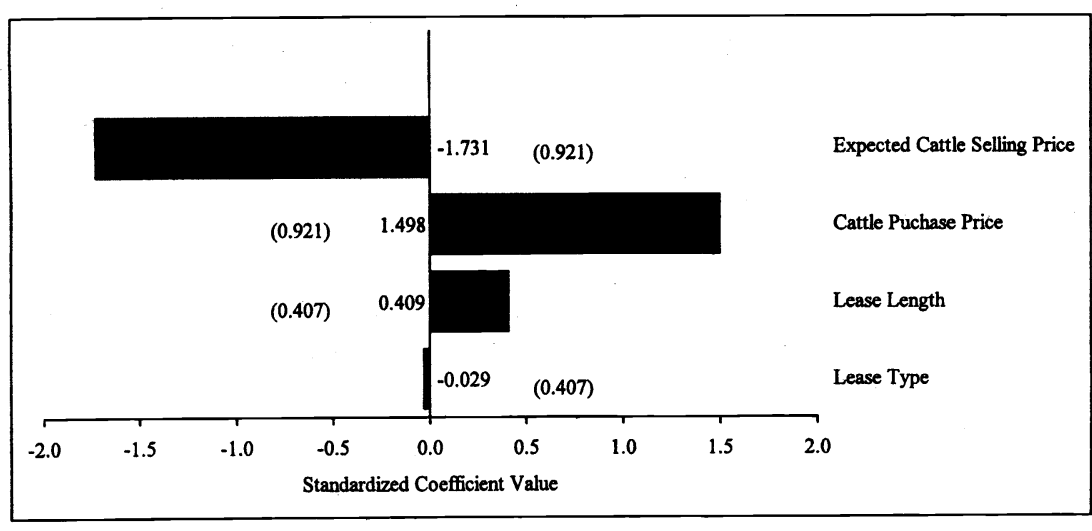

Fig. 5. Relative impact of each input variable on HPI values $\left(R^{2}=0.450\right)$. Standard errors are in parentheses.

Range scientists typically define "proper" stocking rates as a level that will maintain or improve ecological condition (Ohlenbusch and Watson 1994, White and McGinty 1992, Launchbaugh and Owensby 1978). By this definition, all land tenure alternatives examined in this study periodically provided an incentive to overgraze. Herbage production index values in each model declined rapidly from the initial value of 1 , and converged to a steady state ranging between 0.60 and 0.80 . The initial rapid decline in herbage production index values presented in Figures 2 and 3 may not be realistic. Studies suggest vegetation impacts are more gradual. For example, Manley et al. (1997) showed no difference in production among heavy, moderate, and very light stocking rates on mixed-grass prairie after 13 years of grazing. After 18 and 19 years of grazing, however, forage production under heavy grazing was 54 and $69 \%$ of that under moderate, and very light grazing, respectively. Equation 7, therefore, may overestimate the rate of decline in herbage production in the initial years.

Although statistically significant herbage production index (HPI) value differences were observed among alternative lease length scenarios, the differences may not be substantial in terms of actual forage production. The mean difference in the HPI values between the 4- and 12-year ha models was 3 percentage points, or approximately $115 \mathrm{~kg}$ of forage $\mathrm{ha}^{-1}$. The spread between mean HPI values in the 1year and 12-year per head lease models was 5 percentage points, or $180 \mathrm{~kg}$ of forage $\mathrm{ha}^{-1}$. The 1-year ha lease maintained an HPI value substantially lower than all other lease alternatives considered in the study. Mean HPI values in the 1-year ha lease model were 10 and 7 percentage points lower than the 12-year and 4-year ha lease models, amounting to approximately $250 \mathrm{~kg}$ of forage $\mathrm{ha}^{-1}$. This spread was robust over all coefficient values examined in the parametric analysis of Equation 7.

Herbage production index values appeared to be cyclical, following the beef price cycle. Furthermore, cases where vegetative conditions improved under one lease agreement while deteriorating under another were rare, supporting the hypothesis that stocking rates and subsequent herbage production values were primarily driven by livestock price cycles and production costs, not by future forage production concerns. This conclusion is consistent with Torell et al. (1991) suggesting inter-temporal impacts on forage production carry a minor impact on the optimal stocking rate decision.

\section{Lease Type}

Lease type had a relatively small impact on the optimal stocking decision, particularly in the long-term leases. This result can be attributed to the method of modeling lease costs in the per head model. Imposing a minimum lease payment effectively created a mixed variable/fixed cost structure faced by the tenant. At optimal stocking rates below the minimum, the cost structure in the head lease type was identical to that of the ha lease type. Since price/cost margins usually maintained stocking rates below this point, stocking rate incentives were similar across lease types. This study demonstrated, however, that relaxing the required minimum lease payment and converting fixed costs to variable costs reduces the profit-maximizing stocking rate. This suggests pasture lease market conditions or other circumstances that force tenants into lease contracts that require minimum lease payments increase optimal stocking rates.

\section{Limitations of the Study}

This study was based on forage production and price/cost conditions observed in the Kansas Flint Hills. These results may not be applicable to other geographical areas. Inter-temporal impacts of the stocking rate decision vary depending on regional soil conditions and climate. Intertemporal impacts predicted by the model are based on the coefficient values of Equation 7, which were estimated in eastern Colorado (Sims et al. 1976). The Flint Hills grassland appears capable of recovering quickly from overgrazing relative to rangeland in more arid regions. For example, adjusting Equation 7 to increase the vulnerability of the vegetation to overgrazing may be required to model inter-temporal stocking rate impacts on desert rangelands in the southwestern United States. In this fragile, dry environment, grazing impacts on future forage production may be a much more important consideration than what this study suggests for the Flint Hills of Kansas, or Torell et al. (1991) found in eastern Colorado.

This study was intended to identify the economic incentives confronting landlords and tenants, not necessarily to describe actual behavior. Actual behavior depends largely on the perceptions and objectives of the livestock operator. These results assume perfect knowledge of current stocking rate decision impacts on future grazing capacity. Furthermore, this model assumes a profit-maximization objective. Livestock producers have many objectives other than profit (Torell et al. 2001).

Our models did not account for the impact of precipitation and temperature variation on forage availability. Model results, therefore, should be interpreted as "holding weather conditions constant." Actual forage production and vegetation conditions are affected by the weather. Additional research could focus on how incorporating weather risk would affect the results. In addition, the results of this study clearly reveal that profit-maximizing stocking rate behavior results in multi-year cyclical optimal stocking rate behavior. Future research needs to further examine the interface between cattle cycles and stocking rate economic incentives. 


\section{Literature Cited}

Dhuyvetter, K.C. and T.C. Schroeder. 2000. Price-Weight relationships for feeder cattle. Can. J. Agr. Econ. 48: 299-310.

Ellison, L. 1960. Influence of grazing on plant succession of rangelands. The Botanical Review. 26:1-78.

Featherstone, A.M., M.R. Langemeier, and M. Ismet. 1997. A nonparametric analysis of efficiency for a sample of Kansas beef cow farms. J. Agric. and Appl. Econ. 29(1): 175-184.

Federal Reserve Bank of Kansas City. 19751998. Survey of agricultural credit conditions. Federal Reserve Bank of Kansas City news release. Kansas City, Mo.

Hart, R.H. 1972. Forage yield, stocking rate, and beef gains on pasture. Herbage Abstracts. 42:345-353.

Hart, R.H. 1991. Managing range cattle for risk - the STEERISK spreadsheet. J. Range Manage. 44(3):227-231.

Hart, R.H. 1993. Viewpoint: "invisible colleges" and citation clusters in stocking rate research. J. Range Manage. 46:378-382.

Hart, R.H., M.J. Samuel, P.S. Test, and M.A. Smith. 1988. Cattle, vegetation, and economic responses to grazing systems and grazing pressure. J. Range Manage. 41:282-286.

Jones, R.D. and K.C. Dhuyvetter. 1999. Summer grazing of steers in eastern Kansas. KSU Farm Management Guide MF 1008. Kansas State Univ. Agr. Exp. Sta. and Cooperative Ext. Serv. Manhattan, Kan.
Jones, R.J. and R.L. Sandland. 1974. The relation between animal gain and stocking rate. Derivation of the relation from the results of grazing trials. J. Agr. Sci. 83:335-342.

Kansas Agricultural Statistics Service. 19751998. Bluestem Pasture Reports. Topeka Kan.

Launchbaugh, J.L. 1957. The effect of stocking rate on cattle gains on native shortgrass vegetation in west-central Kansas. Kansas Agr. Exp. Sta. Bull. No. 394, Manhattan, Kan.

Launchbaugh, J.L. and C.E. Owensby. 1978. Kansas rangelands, their management based on a half century of research. Kansas Agr. Exp. Sta. Bull. No. 622, Manhattan, Kan.

Manley, W.A., R.H. Hart, M.J. Samuel, M.A. Smith, J.W. Waggoner Jr., and J.T. Manley. 1997. Vegetation, cattle, and economic responses to grazing strategies and pressures. J. Range Manage. 50: 638-646.

Mark, D.R., T.C. Schroeder, and R.D. Jones. 2000. Identifying economic risk in cattle feeding. J. Agribus. 18(3):331-334.

McCollum, T.F. III, R.L. Gillen, B.R. Karges, and M.E. Hodges. 1999. Stocker cattle response to grazing management in tallgrass prairie. J. Range Manage. 52:120-126.

Ohlenbusch P.D. and S.L. Watson. 1994. Stocking rate and grazing management. Cooperative Ext. Serv. Bull. MF-1118, Kansas State Univ. Manhattan, Kan.

Pope, C.A. III and G.L. McBryde. 1984. Optimal stocking of rangeland for livestock production within a dynamic framework. West. J. Agr. Econ. 9:160-169.
Pindyck, R.S. and D.L. Rubinfeld. 1998. Econometric models and economic forecasts, $4^{\text {th }}$ ed. Irwin/McGraw Hill. Boston, Mass.

Shoop, M.C. and E.H. McIlvain. 1971. Why some cattlemen overgraze - and some don't. J. Range Manage. 24:252-257.

Sims, P.L., B.E. Dahl, and A.H. Denham. 1976. Vegetation and livestock response at three grazing intensities on Sandhill rangeland in eastern Colorado. Colorado State Univ. Agr. Exp. Sta. Bull. No.130, Fort Collins, Colo.

Smith, E.F. and C.E. Owensby. 1978. Intensive early stocking and season long stocking of Kansas Flint Hills range. J. Range Manage. 31:14-17.

Torell, L.A., K.S. Lyon, and E.B. Godfrey. 1991. Long-run versus short-run planning horizons and the rangeland stocking decision. Amer. J. Agr. Econ. 73:795-807.

Torell, L.A., N.R. Rimbey, J.A. Tanaka, and S.A. Bailey. 2001. The lack of profit motive for ranching: implications for policy. In: Current Issues in Rangeland Resource Economics. A Western Regional Research Publication. New Mex. State Univ. Agric. Exp. Sta. Research Report 737. Las Cruces N.M.

White, L.D. and A. McGinty. 1992. Stocking rate decisions, key to successful ranch management. Texas Agr. Ext. Serv. Bull. B-5036, College Station, Tex.

Workman, J.P. 1986. Range economics. MacMillan Publishing Co. New York, N.Y. 